\title{
A Cross-Sectional Study on Diabetes Mellitus Type-2 at a Tertiary Care Hospital
}

\author{
Amit Sharma ${ }^{1 *}$, Pooja Sharma ${ }^{2}$, Ankit Gaur ${ }^{2}$, Manik Chhabra ${ }^{2}$ and Rupinderjeet Kaur ${ }^{3}$ \\ ${ }^{1}$ Research Scholar, Uttarakhand Technical University, Dehradun, UK \& Associate Professor, Department of Pharmacy Practice, ISF College of Pharmacy, \\ Moga, (Punjab) India
}

${ }^{2}$ Department of Pharmacy Practice, ISF College of Pharmacy, Moga, Punjab

${ }^{3}$ Assistant Professor, Department of Medicine, G.G.S.M.C.H, Faridkot, Punjab

Submission: October 07, 2017; Published: November 21, 2017

"Corresponding author: Amit Sharma, 1Research Scholar, Uttarakhand Technical University, Dehradun, UK \& Associate Professor, Department of Pharmacy Practice, ISF College of Pharmacy, Moga, (Punjab) India, Email: choice.amit@gmail.com

\begin{abstract}
Introduction: Drug utilization research is a collection of descriptive and analytical methods for the quantification, understanding and evaluation of the processes of prescribing, dispensing, and consumption of medicines, and for the testing of interventions to boost the quality of these processes. Diabetes is a group of metabolic diseases characterized by hyperglycemia resulting from defects in insulin secretion, insulin action, or both.
\end{abstract}

Methodology: In this prospective study a total 1150 in-patients were enrolled who were suffering from diabetes mellitus type- 2 at department of medicine in Guru Gobind Singh Medical College and Hospital, Faridkot, Punjab, India. Aim of the study was to evaluate the demographic data of the patients who are treated with oral diabetes medications and drugs used for different diabetic complications as well as to evaluate the prescribing pattern, duration of stay and cost of the therapy. The data was analyzed by using SPSS ver.24.

Result: The diabetes mellitus type-2was found to be most prevalent $36.7 \%$ in the age group of 51 - 60 years. Females were also founded more prevalent to the diabetes mellitus type-2. Familial association with diabetes mellitus type- 2 was seen in $49.3 \%$ of the patients. Cost of total medication of diabetic patients with and without complications was found to be INR 890 and 750 respectively.

Conclusion: The present study helps to find out current prescribing pattern of oral diabetic medications with different co-morbidities with respect to diagnosis, cost of treatment and it also highlight the need for comprehensive management of diabetic patients, including life style changes, dietary control, hypoglycemic agents, cardiovascular prevention, treatment of complications and co-morbidity. Therefore, through the existing prescribing patterns, attempts can be made to improve the quality and efficiency of drug therapy

Keywords: Diabetes Mellitus Type-2; Diabetic retinopathy; Diabetic nephropathy; Diabetic neuropathy; Drug utilization review; Pharmacoeconomic evaluation

\section{Introduction}

Drug utilization research is an collection of descriptive and analytical methods for the quantification, understanding and evaluation of the processes of prescribing, dispensing, and consumption of medicines, and for the testing of interventions to boost the quality of these processes [1]. They are foremost exploratory tools to assess whether drug therapy is rational or not and for creating a sound socio-medical and economic basis for healthcare decision making [2]. Drug utilization review combined with elements of disease management expands the focus from only drug-specific problems to an approach that also uses treatment guidelines and algorithms to evaluate the appropriateness of drug therapy in the context of treating particular diseases. This requires consideration of health outcomes and pharmacoeconomic findings [3].

Diabetes Mellitus (DM) is one of the oldest diseases known to man, which was the first reported in Egyptian literature about 3000 years ago. The term 'diabetes' was first coined by Araetaeus of Cappodocia (81-133 AD). Mellitus (honey sweet) was added by Thomas Willis (Britain) in 1675, when he detected sweetness in urine. It is said that it was first noticed by the ancient Indians; Shushrutha had named it as 'Madhumeha' [4]. Avicenna, is the famous Arabian physician who first described the complications 
and progression of the disease [5]. Diabetes is a group of metabolic diseases characterized by hyperglycemia resulting from defects in insulin secretion, insulin action, or both. The chronic hyperglycemia of diabetes is associated with long-term damage, dysfunction and failure of various organs, especially the eyes, kidneys, nerves, heart and blood vessels [6]. According to IDF [7], the number of people with diabetes in the world in 2013 was 382 million, which is going to increase to almost 592 million by 2035. India has the hesitant similarity of being home to a large number of people suffering from diabetes. According to IDF, 65.1 million of adults in India suffered from diabetes in the year [8]. It has been predicted that the prevalence of diabetes in the adult population in India will be $6 \%$ by the year 2025 [9].

\section{Complications of diabetes mellitus}

The negative impact of hyperglycemia on endothelial function and pathological changes observed in diabetes is supported in the literature $[10,11]$. Endothelial cells in vitro are exquisitely sensitive to high glucose (25mM) [10] have carefully characterized four major molecular signaling mechanisms activated by hyperglycemia in endothelial cells and other cell types vulnerable to hyperglycemic injury. These include activation of PKC (via diacylglycerol), increased hexosamine pathway flux, increased advanced glycation end product (AGE) formation, and increased polyol pathway flux.

I. Microvascular complications

a. Diabetic retinopathy

b. Diabetic nephropathy

c. Diabetic neuropathy

II. Macrovascular Complications Of Diabetes

\section{Methodology}

This prospective study was conducted at department of medicine in Guru Gobind Singh Medical College and Hospital, Faridkot, Punjab, India. The study was carried out for the period of 8 months (September, 2015 to April 2016) after getting approval from the Institutional Ethical Committee of the ISF College of Pharmacy. Aim of the study was to evaluate the demographic data of the patients who are treated with oral diabetes medications and drugs used for different diabetic complications as well as to evaluate the prescribing pattern, duration of stay and cost of the therapy. Data was collected from patient case sheet and medications chart and laboratory tests reportsin to the data collection form after signing the Informed consent form by the patient. The data was analyzed by using SPSS ver.24.

\section{Study population}

The study population included In-patients of either gender diagnosed with Diabetic comorbidities and diabetes mellitus typeII. A total 1150 patients of patients were enrolled into the study based on inclusion and exclusion criteria. Those who were Type-I diabetic patient, gestational diabetic patient, outpatient of diabetes and the patients who were not willing to participate was excluded from the study.

\section{Results}

\section{Demographic data of the patients}

In demographic data of the patient's various variables such as age, weight distribution, gender, family history of diabetes and social habits such as smoking, drug abuse, alcoholism were taken of the enrolled patients in the study. In the demographic evaluation female was found to be more prevalent to disease (p-value 0.017). Demographic data of patients is represented in the Table 1.

Table 1: Demographic data of the patients.

\begin{tabular}{|c|c|}
\hline Variable & Percent \\
\hline \multicolumn{2}{|c|}{ Age distribution of the patients (years) } \\
\hline 30-50years & 24.7 \\
\hline $51-70$ & 68.7 \\
\hline$>70$ & 6.7 \\
\hline \multicolumn{2}{|c|}{ Weight distribution of the patients $(\mathrm{Kg})$} \\
\hline \multicolumn{2}{|l|}{ Weight } \\
\hline $50-70$ & 52 \\
\hline $71-80$ & 38 \\
\hline$>81$ & 10 \\
\hline \multicolumn{2}{|c|}{ Gender distribution of the patients } \\
\hline Male & 46.0 \\
\hline Female & 54.0 \\
\hline Yes & 49.3 \\
\hline No & 50.7 \\
\hline \multicolumn{2}{|c|}{ Dialysis status of the patients (years) } \\
\hline$>10$ & 28.7 \\
\hline$<5$ & 46.0 \\
\hline $6-10$ & 25.3 \\
\hline \multicolumn{2}{|c|}{ Social habits of the patients } \\
\hline Alcoholic & 23.3 \\
\hline Alcoholic+Drug Abuse & 9.3 \\
\hline Alcoholic+Smoker & 10.0 \\
\hline Drug Abuse & 3.3 \\
\hline Not Addicted & 52.7 \\
\hline Smoker & 1.3 \\
\hline
\end{tabular}

\section{Status of complications of diabetic patients}

It includes variables such as No complications, microvascular complications,macrovascular complications, infections, acute complications and Complications of complications. Details are shown in Table 2. 


\section{Advanced Research in Gastroenterology \& Hepatology}

Table 2: Status of diabetic complications.

\begin{tabular}{|c|c|}
\hline Complications & Percent (\%) \\
\hline No complications & 8.67 \\
\hline Microvascular & 16 \\
\hline Macrovascular & 28.67 \\
\hline Infections & 11.33 \\
\hline Acute complication & 3.33 \\
\hline Complications of complications & 32 \\
\hline Total & 100 \\
\hline
\end{tabular}

\section{Status of comorbidities}

Out of 1150 Diabeties Mellitus Type-2 patients admitted, 91.34\% patients had various comorbidities along with diabetes; remaining $8.67 \%$ patients didn't have any comorbidity. Among DM patients with comorbidities, $6.67 \%$ patients had infections, $0.7 \%$ patients had respiratory, $0.7 \%$ patients had haematological, $0.7 \%$ had gastrointestinal disorder $28.67 \%$ patients had cardiovascular, $2 \%$ had endocrine, $12 \%$ had hepatic disorder, (13.34\%) had renal disorder, (2.62\%) had Triopathy, and (26.67\%) patients had more than one comorbidities.

\section{Laboratory values}

Fasting blood sugar level of the diabetic patient during admission: On evaluation of FBS level, Majority of them had FBS range $201-300 \mathrm{mg} / \mathrm{dl}$ that is, $41.3 \%$ patients and $6.7 \%$ patients had value $>500 \mathrm{mg} / \mathrm{dl}$. Mean and Standard deviation were found to be $292 \pm 115.98$.

SGOT and SGPT: In admitted patients, 65.3\% had normal SGOT level and $67.3 \%$ had normal SGPT level and remaining 34.7\% and $32.7 \%$ had abnormal SGOT and SGPT level respectively. Mean and standard deviation of SGOT were found to be $57.59 \pm 105.48$. Mean and standard deviation were found to be $51.4 \pm 87.08$.

\section{Sr. creatinine}

On evaluation of patient admitted, 57.3\% had normal level of sr. creatinine and $42.7 \%$ had abnormal level. Mean and standard deviation were found to be $2.62 \pm 2.6$.

\section{Lipid profile}

Table 3: Laboratory values of the diabetic patients.

\begin{tabular}{|c|c|}
\hline SGOT & Percent (\%) \\
\hline$>35 \mathrm{IU} / \mathrm{L}$ & 34.7 \\
\hline $0-35 \mathrm{IU} / \mathrm{L}$ & 65.3 \\
\hline \multicolumn{2}{|c|}{ SGPT } \\
\hline >35 IU/L & 32.7 \\
\hline $0-35 \mathrm{IU} / \mathrm{L}$ & 67.3 \\
\hline
\end{tabular}

\begin{tabular}{|c|c|}
\hline \multicolumn{2}{|c|}{ Sr. creatinine } \\
\hline$>1.3 \mathrm{mg} / \mathrm{dl}$ & 42.7 \\
\hline $0.8-1.3 \mathrm{mg} / \mathrm{dl}$ & 57.3 \\
\hline \multicolumn{2}{|c|}{ CHL } \\
\hline $200-239 \mathrm{mg} / \mathrm{dl}$ & 30.7 \\
\hline$<200 \mathrm{mg} / \mathrm{dl}$ & 62.0 \\
\hline$>240 \mathrm{mg} / \mathrm{dl}$ & 7.3 \\
\hline \multicolumn{2}{|c|}{ LDL } \\
\hline $100-129 \mathrm{mg} / \mathrm{dl}$ & 2.7 \\
\hline $130-159 \mathrm{mg} / \mathrm{dl}$ & 32.7 \\
\hline $160-189 \mathrm{mg} / \mathrm{dl}$ & 59.3 \\
\hline$>190 \mathrm{mg} / \mathrm{dl}$ & 2.7 \\
\hline \multicolumn{2}{|c|}{ HDL } \\
\hline$>40 \mathrm{mg} / \mathrm{dl}$ & 74.0 \\
\hline$<40 \mathrm{mg} / \mathrm{dl}$ & 26.0 \\
\hline \multicolumn{2}{|c|}{ TG } \\
\hline $150-199 \mathrm{mg} / \mathrm{dl}$ & 36.0 \\
\hline$<150 \mathrm{mg} / \mathrm{dl}$ & 53.3 \\
\hline $200-499 \mathrm{mg} / \mathrm{dl}$ & 10.7 \\
\hline
\end{tabular}

On evaluation of patients for lipid profile, majority of them had CHL level $<200 \mathrm{mg} / \mathrm{dl}$ that is, $62 \%$, majority had LDL level between $160-189 \mathrm{mg} / \mathrm{dl}$ that is, $59.3 \%$. Moreover, $74 \%$ patients had $>40 \mathrm{mg} /$ $\mathrm{dl}$ and maximum patients had $\mathrm{TG}>150 \mathrm{mg} / \mathrm{dl}$ that is, $53.3 \%$. Laboratory values details are shown in (Table 3).

\section{Choice of anti diabetic drugs}

On evaluation of prescription pattern of anti-diabetic drugs, Admitted Diabetes mellitus Type- 2 patients 52\% patients were on mono therapy followed by $28 \%$ patients were on two drug combinations and $20 \%$ patients were on three drug combinations which is represented in (Table 4).In dosage regimen the p-value of mono therapy was found to be 0.01 and p-value of two drugs combination was 0.01 and three drugs combination p-value was 0.02 subsequently.

\section{Pharmacoeconomic evaluation}

Cost of total medication of diabetic patient's type-2 with and without complications was found to be INR 890 and 750 respectively. Out of diabetic mellitus type-2 patients with complications, 50\% patients underwent dialysis for that cost per patient was INR 6000 per month and annual cost of intervention per patient was found to be INR 18,000. Details are shown in the Table 5 below. 
Table 4: Choice of anti-diabetic drug.

\begin{tabular}{|c|c|c|c|c|c|}
\hline Monotherapy & $\begin{array}{l}\text { No. of patients } \\
\text { No. of patients }\end{array}$ & Two drugs combinations & $\begin{array}{c}\text { No. of } \\
\text { patients }\end{array}$ & Three drugs combinations & No. of patients \\
\hline $\begin{array}{c}\text { Insulin } \\
\text { Metformin } 500 \mathrm{mg} \\
\text { Metformin } 1000 \mathrm{mg}\end{array}$ & $\begin{array}{l}720 \\
40 \\
20\end{array}$ & $\begin{array}{l}\text { Insulin Glargine+Voglibose } \\
\text { 0.3mg } \\
\text { Huminsulin R+Glipizide } \\
\text { Huminsulin R+Huminsulin } \\
\text { NPH } \\
\text { Huminsulin R+Insulin Glargine } \\
\text { Lupinsulin R+Met 1000mg } \\
\text { Lupinsulin R+Voglibose 0.3mg } \\
\text { Lupinsulin R+Tenegliptin } \\
\text { Lupinsulin R+Pioglitazone } \\
\text { 15mg } \\
\text { Met 500mg+Glibenclamide } \\
\text { 5mg } \\
\text { Met 500mg+Gliclazide 80mg } \\
\text { Met 500mg+Glimperide 2mg } \\
\text { Met 1000mg+Huminsulin R } \\
\text { Met 1000mg+Glimepride }\end{array}$ & $\begin{array}{l}420 \\
10 \\
30 \\
50 \\
20 \\
80 \\
30 \\
30 \\
20 \\
50 \\
30 \\
10 \\
10\end{array}$ & $\begin{array}{c}\text { Huminsulin R+Met } \\
\text { 500mg+Glimeperide } 2 \mathrm{mg} \\
\text { Huminsulin R+Met 500mg+Tenegliptin } \\
\text { Huminsulin R+Met 500mg+Vidagliptin } \\
\text { 50mg } \\
\text { Lupinsulin R+Met } \\
\text { 1000mg+Glibenclamide } \\
\text { Lupinsulin R+ Met1000mg+Glimperide } \\
\text { 3mg } \\
\text { Lupinsulin+Met1000mg+Glipizide } \\
\text { Lupinsulin+Glimperide } \\
\text { 2mg+Pioglitazone 15mg } \\
\text { Lupinsulin+Met 2000mg+Glipizide } \\
\text { Met 500mg +Glibenclamide } 5 \mathrm{mg} \\
+ \text { Voglibose0.3mg } \\
\text { Met 1000mg+Glipizide+Tenegliptin } \\
\text { Metformin 1000mg+Metformin } \\
\text { 500mg+Glimperide 1mg }\end{array}$ & $\mathrm{s}$ \\
\hline
\end{tabular}

Table 5: Annual cost of insulin, OADs and insulin plus OADs per patients.

\begin{tabular}{|c|c|c|c|c|}
\hline Cost of Drugs (In Rupees) & $\begin{array}{c}\text { DM Without Complication } \\
\text { Median ( IQR) }\end{array}$ & $\begin{array}{c}\text { DM With Complication } \\
\text { Median (IQR) }\end{array}$ & $\begin{array}{c}\text { Average Cost of Diabetic } \\
\text { Drug Per Patient Per } \\
\text { Month Median (IQR) }\end{array}$ & $\begin{array}{c}\text { Average Cost of Diabetic } \\
\text { Drug Per Patient Per } \\
\text { Annum Median (IQR) }\end{array}$ \\
\hline Insulin & $140(140)$ & $140(10)$ & $560(40)$ & $6,720(480)$ \\
\hline OADs & $60(120)$ & $80(100)$ & $320(400)$ & $3,840(4,800)$ \\
\hline Insulin+OADs & $180(60)$ & $220(130)$ & $880(520)$ & $10,560(6,240)$ \\
\hline $\begin{array}{c}\text { Cost of total medication } \\
\text { charges }\end{array}$ & $\begin{array}{c}\text { DM with complication } \\
\text { Median (iqr) }\end{array}$ & $\begin{array}{c}\text { DM without complication } \\
\text { Median (iqr) }\end{array}$ & $\begin{array}{c}\text { Cost of total medication } \\
\text { charges }\end{array}$ & $\begin{array}{c}\text { DM with complication } \\
\text { Median (iqr) }\end{array}$ \\
\hline In Rs & $890(287)$ & $750(1207)$ & In Rs & $890(287)$ \\
\hline $\begin{array}{c}\text { Cost of intervention per } \\
\text { patients }\end{array}$ & No. Of patients (\%) & Cost per patient In rs & Type of intervention & No. Of patients (\%) \\
\hline Type of intervention & $50(50)$ & 6,000 per month & Dialysis & 50 (50) \\
\hline Dialysis & & \begin{tabular}{c} 
cost of intervention per \\
\hline
\end{tabular}
\end{tabular}

\section{Discussion}

Diabetes Mellitus Type-2was found to be most prevalent 36.7\% in the age group of 51 - 60 years as aging causes increase prevalence of diabetes and carbohydrate intolerance in the elderly due to associated decrease in insulin secretion in response to glucose load as well as increased insulin resistance in peripheral tissues [12]. Further, insulin sensitivity also decreases with increasing age and obesity [13-16].

Diabetes Mellitus Type- 2 was also found to be most prevalent $23.3 \%$ in the weight distribution of $71-75 \mathrm{~kg}$, the people who are overweight or have obesity. Out of these patients suffering from type 2 diabetes mellitus, more than half $54 \%$ of the patients were females as compared to males $46 \%$ this shows that females are more prevalent to this disease. Familial association with diabetes mellitus type 2 was seen in $49.3 \%$ of the patients. A study conducted by M. S. [17] reported the same.

During the study period, $52 \%$ patients were on mono therapy followed by $28 \%$ patients were on two drug combinations and $20 \%$ patients were on three drug combinations. Among mono therapy, insulin is most prescribed drug in $48 \%$ of the patients followed by (biguanides) metformin 500mg for $2.67 \%$ and metformin $1000 \mathrm{mg}$ in $1.34 \%$ and $\mathrm{p}$-value is 0.01 . A study reported improved glycemic control following the addition of sulfonylureas to metformin, but deterioration resumes as early as 6 months [18]. Furthermore 
lifestyle modifications, inclusive of dietary modification, regular physical activity and weight reduction are indicated for prevention of diabetes mellitus type-2 [9,12-15,19].

On evaluation of prescribing trends for individual class of drugs used in management of diabetes mellitus type-2, insulin consumption was high $86.67 \%$, followed by biguanides $38 \%$ then sulfonylurea $28 \%$. Reported biguanides $24.5 \%$ and sulphonylureas $19.9 \%$ as the most commonly prescribed OHAs [20]. Reported the proportion of newly diagnosed patients initially treated with metformin increased from $51 \%$ to $65 \%$, whereas those receiving sulfonylureas decreased from $26 \%$ to $18 \%$ [21]. Boccuzzi et al., reported consumption of sulphonylureas that of $66.4 \%$ and metformin $24.3 \%$ [22]. A study from Taiwan reported sulfonylureas as the most commonly prescribed drug class followed by biguanides [23].

\section{Conclusion}

The present study helps to find out current prescribing pattern of oral diabetic medications with different co-morbidities with respect to diagnosis, cost of treatment and it also highlight the need for comprehensive management of diabetic patients, including lifestyle changes, dietary control, hypoglycemic agents, cardiovascular prevention, treatment of complications and co-morbidity. Therefore, through the existing prescribing patterns, attempts can be made to improve the quality and efficiency of drug therapy. Hence in future, improving the patient knowledge regarding the drug therapy, dose and frequency will perhaps improve the quality of life in Type II diabetic patients.

\section{Acknowledgement}

We thank Mr. Parveen Garg, Chairman; Prof. GD. Gupta, Principal-Cum-Director, and Department of Pharmacy Practice, ISF College of Pharmacy for providing support of Micromedex software for this study. The corresponding author had full access to all data in the study and had final responsibility for the decision to submit for publication.

\section{References}

1. Bergman U (2006) The history of the Drug Utilization Research Group in Europe. Pharmacoepidemiol Drug Safety 15(2): 95-98.

2. Sutharson L, Hariharan RS, Vamsadhara C (2003) Drug utilization study in diabetology outpatient setting of A tertiary hospital. Indian Journal of Pharmacology 35(4): 237-240.

3. Truter I (2008) A review of drug utilization studies and methodologies. Jordan Journal of Pharmaceutical Sciences 1(2): 91-104.

4. Ahmad N, Feyes DK, Nieminen AL, Agarwal R, Mukhtar H (1997) Green tea constituent epigallocatechin-3-gallate and induction of apoptosis and cell cycle arrest in human carcinoma cells. Journal of the National Cancer Institute 89(24): 1881-1886.
5. Olokoba AB, Obateru OA, Olokoba LB (2012) Type 2 diabetes mellitus: a review of current trends. Oman Med J 27(4):269-273.

6. American Diabetes Association (2012) Diagnosis and classification of diabetes mellitus. Diabetes Care 35(Supplement 1): S64-S71.

7. Asia S, Aguiree F, Brown A, Cho N, Dahlquist G, et al. (2013) IDF Diabetes Atlas. IDF Diabetes Atlas ( $6^{\text {th }}$ edn), pp. 3-4.

8. (2013) International Diabetes Federation. IDF Diabetes Atlas ( $6^{\text {th }}$ edn).

9. King H, Aubert RE, Herman WH (1998) Global burden of diabetes, 1995-2025: Prevalence, numerical estimates, and projections. Diabetes Care 21(9): 1414-1431.

10. Nishikawa T, Edelstein D, Du XL, Sho ichi Yamagishi, Takeshi Matsumura, et al. (2000) Normalizing mitochondrial superoxide production blocks three pathways of hyperglycemic damage. Nature 404(6779): 787-790.

11. Sheetz MJ, King GL (2002) Molecular understanding of hyperglycemia's adverse effects for diabetic complications. JAMA. 288(20): 2579-2588.

12. Meneilly GS, Elliott T, Tessier D, Hards L, Tildesley H (1996) NIDDM in the elderly. Diabetes Care 19(12): 1320-1325.

13. Rizvi A (2007) Management of diabetes in older adults. Am J Med Sci. 333(1): 35-47.

14. Nelson ME, Rejeski WJ, Blair SN, Duncan PW, Judge JO, et al. (2007) Physical activity and public health in older adults: Recommendation from the American College of Sports Medicine and the American Heart Association. Medicine and Science in Sports and Exercise 39(8): 14351445 .

15. Kirkman MS, Briscoe VJ, Clark N, Florez H, Haas LB, et al. (2012) Diabetes in older adults. Diabetes Care 35(12): 2650-2664.

16. Nelson ME, Rejeski WJ, Blair SN, Duncan PW, Judge JO, et al. (2007) Physical activity and public health in older adults: Recommendation from the American College of Sports Medicine and the American Heart Association. Circulation 116(9): 1094-1105.

17. Sultana G, Kapur P, Aqil M, MS Alam, KK Pilli (2010) Drug utilization of oral hypoglycemic agents in a university teaching hospital in India. J Clin Pharm Ther 35(3): 267-277.

18. Cook MN, Girman CJ, Stein PP, Alexander CM, Holman RR (2005) Glycemic control continues to deteriorate after sulfonylureas are added to metformin among patients with type 2 diabetes. Diabetes Care 28(5): 995-1000.

19. Markku L, Lehto S (1997) Epidemiology of macrovascular disease in diabetes. Diabetes Rev 5(4): 294-315.

20. Das P, Das BP, Rauniar GP, Roy RK, Sharma SK (2011) Drug utilization pattern and effectiveness analysis in diabetes mellitus at a tertiary care centre in Eastern Nepal. Indian J Physiol Pharmacol 55(3): 272-280.

21. Desai NR, Shrank WH, Fischer MA, Avorn J, Liberman JN, et al. (2012) Patterns of medication initiation in newly diagnosed diabetes mellitus: quality and cost implications. Am J Med 125(3): 302.

22. Health TN, Ex N (2001) Utilization of Oral Hypoglycemic Agents 24(8).

23. Chiang CW, Chiu HF, Chen CY, Wu HL, Yang CY (2006) Trends in the use of oral antidiabetic drugs by outpatients in Taiwan: 1997-2003. J Clin Pharm Ther 31(1): 73-82. 
This work is licensed under Creative Commons Attribution 4.0 License

DOI: 10.19080/ARGH.2017.08.555726

\section{Your next submission with Juniper Publishers} will reach you the below assets

- Quality Editorial service

- Swift Peer Review

- Reprints availability

- E-prints Service

- Manuscript Podcast for convenient understanding

- Global attainment for your research

- Manuscript accessibility in different formats

( Pdf, E-pub, Full Text, Audio)

- Unceasing customer service

Track the below URL for one-step submission

https://juniperpublishers.com/online-submission.php 